\title{
Z NADZIEJĄ NA POWRÓT - PERSPEKTYWA BADAŃ NAD UCHODŹCAMI ZE SKANDYNAWII W RZECZPOSPOLITEJ OBOJGA NARODÓW ZA PANOWANIA ZYGMUNTA III
}

\author{
Wojciech Krawczuk \\ http://orcid.org/0000-0001-9191-9415
}

Uniwersytet Jagielloński w Krakowie

\author{
ABSTRACT \\ HOPING FOR A RETURN: THE PERSPECTIVES IN RESEARCH ON \\ REFUGEES FROM SCANDINAVIA IN THE POLISH-LITHUANIAN \\ COMMONWEALTH DURING THE REIGN OF SIGISMUND III
}

After the Swedish Civil War of 1598 hundreds of exiles left their home country and fled to the Polish-Lithuanian Commonwealth, hoping for the protection of king Sigismund. Composition of this group and ways the refugees were helped are known thanks to the conducted research. The king could not support exiles too openly because of the gentry's reluctance to strangers, but they received general salary and small privileges. However, many actions of this group are still unexplored. One can especially mention their participation in the construction of the Royal Fleet, activity of this group in Gdańsk (Danzig), and other actions carried out by the exiles in support of the Polish branch of House of Vasa.

Keywords: refugees, Sigismund III, Sweden, Finland, the Polish-Lithuanian Commonwealth.

Słowa kluczowe: uchodźcy, Zygmunt III, Szwecja, Finlandia, Rzeczpospolita Obojga Narodów.

22 sierpnia 1599 roku królewna Anna Wazówna zwróciła się do Szymona Bahra, królewskiego faktora w Gdańsku, żeby zaopiekował się jej sługą. Peter nie znał języka, chodziło o znalezienie mu towarzystwa ${ }^{1}$. List zachował się w szwedzkiej registraturze Zygmunta III.

Pismo dobrze świadczy o królewnie, a zarazem jest przykładem codziennych kłopotów licznej grupy uchodźców, którzy pojawili się w Rzeczpospolitej pod koniec XVI wieku i pozostać w niej mieli jeszcze przez lat kilkadziesiąt. Peter był Szwedem

${ }^{1}$ Riksarkivet Stockholm, Riksregistraturet, vol. 87, k. 449 v.

$\square \quad$ Adres do korespondencji: wojciech.krawczuk@uj.edu.pl 
albo Finem. Nawet w Gdańsku, gdzie porozumiewano się po niemiecku, mógł czuć się obco. Choć w królewskich registraturach mamy tysiące nadań wiosek, urzędów, przywilejów dla możnych, nie za wiele jest świadectw bezinteresownego zainteresowania losem sług.

Temat obecności Szwedów oraz Finów w Polsce i na Litwie za panowania Zygmunta III jest zgłębiany przez historyków już od dłuższego czasu, można jednak zauważyć, że wiele tematów pozostaje jeszcze nieopracowanych. Ich wskazanie jest celem tego artykułu.

W początkach rządów Zygmunta III Szwedzi i Finowie byli zazwyczaj dworzanami towarzyszącymi królowi oraz jego świcie. Mieli duży wpływ na politykę, co budziło niechęć szlachty, uzewnętrznioną na sejmie inkwizycyjnym w 1592 roku. Choć wpływy Szwedów z biegiem lat malały, pierwsza wyprawa króla do Szwecji w 1593 roku, zakończona koronacją w roku 1594, zdawała się początkiem nowej unii, pokojowego współistnienia rozmaitych nacji. Ten pierwszy okres bytności Szwedów w Polsce został zbadany przez Jerzego Michalewicza ${ }^{2}$.

Rządza władzy księcia Karola Sudermańskiego doprowadziła do rozpętania wojny domowej, przegranej przez Zygmunta III. Pierwsi uchodźcy pojawili się w Rzeczpospolitej już około 1595 roku, w latach 1598 i 1599 przybyła zaś największa ich fala - kilkusetosobowa grupa, w której znaleźli się reprezentanci wszystkich niemal stanów Królestwa Szwecji i Wielkiego Księstwa Finlandii³. Dysponujemy kilkoma opracowaniami dziejów tej zbiorowości, wydaje się jednak, że jej losy kryją nadal niemało tajemnic.

Warto przypomnieć, jakie zagadnienia zostały już wyjaśnione. Znamy więc skład grupy, nazwiska uchodźców, dzięki zachowanym spisom z lat 1600-1620. Porównując te źródła, udało się także odtworzyć przemiany opisywanej społeczności, ze szczególnym uwzględnieniem powrotów tych repatriantów, którzy pogodzili się z Gustawem II Adolfem i wrócili do Szwecji po roku $1611^{4}$.

Wiemy też, w jaki sposób Zygmunt III wspierał uchodźców, swych zwolenników pozostających w Polsce i na Litwie. System był dość skomplikowany i na dworze o tej sprawie milczano ze względu na uwarunkowania wewnętrzne, głównie po to, by nie dawać szlachcie okazji do ataków. Król ustanowił pensję generalną z dochodów portu Gdańska, a po części Elbląga, była ona dzielona przez specjalnie do tego celu wyznaczonych szwedzkich komisarzy, najczęściej królewskich sekretarzy. Oprócz

2 J. Michalewicz, Dwór szwedzki Zygmunta III w latach 1587-1600, „Odrodzenie i Reformacja w Polsce" 1966, t. XI, s. 161-180.

${ }^{3}$ P.P. Szpaczyński, Mocarstwowe dążenia Zygmunta III w latach 1587-1618, Kraków 2013, s. $31-41$.

${ }^{4}$ W. Krawczuk, Wierni królowi. Szwedzi i Finowie w Rzeczpospolitej Obojga Narodów w pierwszej polowie XVII wieku, Kraków 2019. Zob. także: J. Małłek, Stosunki kulturalne Polski i Litwy z państwami skandynawskimi w późnym średniowieczu $i$ w czasach nowożytnych (1385/1397-1795) [w:] Kultura Pierwszej Rzeczypospolitej w dialogu z Europa. Hermeneutyka wartości, t. 1: Wśród krajów pótnocy. Kultura Pierwszej Rzeczypospolitej wobec narodów germańskich, stowiańskich i naddunajskich: mapa spotkań, przestrzenie dialogu, red. M. Han u siew icz-Lavalle e, Warszawa 2015, s. 58-102; K. Ślaski, P. Bninska, The Swedish Emigrants in Poland on the Turn of the $16^{\text {th }}$ Century and Their Part in the Social Life of this Country, „Studia Historica Slavo-Germanica” 1983, vol. 12, s. 155-163. 
tego uchodźcy liczyć mogli na drobniejsze nadania: kaduki, karczmy i kaduki w Prusach Królewskich. Duchowni katoliccy otrzymywali za wstawiennictwem króla rozmaite beneficja kościelne, przede wszystkim kanonie na Warmii. Funkcjonowało dalej kolegium jezuickie w Braniewie, gdzie młodzież ze Skandynawii mogła pobierać nauki na koszt władcy 5 .

Jakie zatem problemy zostały jeszcze do zbadania? Walter Leitsch, twórca czterotomowej monografii poświęconej dworowi Zygmunta III, określił jego strukturę jako skomplikowaną i nieprzejrzystą. W źródłach czy opracowaniach widoczny zazwyczaj jest dwór oficjalny, jego układ, ważni urzędnicy. Królewskim schronieniem na co dzień był natomiast bawarsko-szwabski dwór królowych: Anny Habsburżanki, potem jej siostry Konstancji. Leitsch mógł ukazać barwny obraz tego „wewnętrznego dworu w dworze" tylko dzięki szczęśliwej okoliczności, zachowały się bowiem listy, które obie królowe i ich dworzanie pisali do arcyksiężnej Marii Habsburg, matki władczyń. Jednak w przypadku dworu szwedzkiego nie mamy tak dobrej sytuacji źródłowej. Leitsch stwierdza wprost, że sprawy szwedzkie owiane były tajemnicą ${ }^{6}$.

Mały dwór szwedzki Zygmunta III po roku 1598 zostaje tematem nie w pełni opisanym. Ustalono wprawdzie nazwiska wpływowych dworzan Szwedów, sekretarzy i pisarzy kancelarii szwedzkiej, a nawet szwedzkich trębaczy, których było wedle ordynacji całkiem sporo. Warto byłoby jednak zebrać i usystematyzować informacje o działaniach tej grupy. Okazję do tego dają nam zachowane dwie księgi registratury szwedzkiej obejmujące lata 1597-1600, przechowywane w sztokholmskim Riksarkivet pod sygnaturami Riksregistraturet 86 i 87 . Księga 87 spisana po niemiecku i dotycząca polityki zagranicznej została opracowana i niebawem ukaże się poświęcona jej publikacja. Księga 86, znacznie trudniejsza w odczycie i zapisana po szwedzku, czeka jeszcze na opublikowanie. Dopiero wówczas będzie można uchwycić pierwsze zręby szwedzkiego dworu Zygmunta III, akcje po przegranej w roku 1598 i wycofaniu się sojuszników króla do Polski i do Inflant.

Przy okazji analizy szwedzkiego dworu trzeba zwrócić uwagę na powiązany z tą kwestią temat drabantów królewskich, czyli gwardii przybocznej. Z rozproszonych wzmianek ukazuje się obraz sporej grupy Szwedów wchodzących w skład tej formacji. Odtworzenie dziejów tego oddziału przyniosłoby wiele informacji ważnych dla objaśnienia losów szwedzkich i fińskich uchodźców - byłoby to dopełnienie pracy Mirosława Nagielskiego o gwardii królewskiej za Wazów?

Z powyższymi zagadnieniami łączy się wspomniana już postać królewny Anny Wazówny. Jako luteranka służyła ona wsparciem protestanckim uchodźcom i z racji bardzo dobrych relacji z bratem odgrywała ważną, choć zakulisową rolę w polityce Zygmunta III. Można uznać, że właśnie ona jako jedyna z grupy skandynawskich uchodźców przetrwała w pamięci zbiorowej i lokalnej. Świadczy o tym choćby jej pomnik w Brodnicy, wzniesiony niedawno, w 2005 roku, ale też odznaka „Śladami królewny Anny Wazówny" nadawana przez oddział PTTK w Grudziądzu. Istotnym

${ }^{5}$ W. Krawczuk, Wierni królowi, s. 89-117.

${ }^{6}$ W. Leits ch, Das Leben am Hof König Sigismunds III. von Polen, Band III, Wien 2009, s. 1650.

${ }^{7}$ M. Nagielski, Spoteczny i narodowy skład gwardii królewskiej za dwóch ostatnich Wazów (1632-1668), „Studia i Materiały do Historii Wojskowości” 1988, nr 30, s. 61-102. 
zadaniem badawczym pozostaje wydanie zachowanych listów Anny Wazówny - jest ich całkiem sporo, lecz trudność polega na ich rozproszeniu w archiwach polskich i szwedzkich. Edycji tych listów podjął się zespół stworzony niedawno przez Karola Łopateckiego. Dopiero po ich opracowaniu będzie można przyjrzeć się szczegółom dotyczącym funkcjonowania dworu królewny.

Jeszcze innym problemem jest dokładne opisanie grupy, która osiedliła się w Gdańsku. Z różnych względów - językowych, religijnych, kulturowych - miasto było najchętniej wybierane przez Szwedów i Finów; tam również osiadły szwedzkie brygidki wypędzone przez Karola Sudermańskiego z Vadsteny. Prace Wojciecha Łygasia i Sławomira Kościelaka, którymi dysponujemy, wskazują na konieczność podjęcia dalszych kwerend i badań8.

Z Gdańskiem oraz Puckiem wiąże się inny, rozległy temat organizacji floty królewskiej. Zygmunt III zwracał uwagę na kwestię wyposażenia i organizowania sił morskich, a dużą rolę odgrywali w tych pracach właśnie uchodźcy ze Szwecji i Finlandii. Odsiecz dla Kalmaru i wyprawa na Älvsborg w 1599 roku zostały już opracowane, podobnie zresztą jak czas działania Królewskiej Komisji Okrętowej, mniej więcej od 1627 roku. Pozostaje jednak nie tak dokładnie zbadany długi okres pomiędzy tymi datami, związany przede wszystkim z postacią Jana Weihera, starosty puckiego. Marian Huflejt zwrócił ostatnio uwagę na wątek udziału cudzoziemców w tworzeniu floty króla, niedostatecznie uwzględniony w dotychczasowych pracach historyków ${ }^{9}$. Pośród nich było wielu Szwedów i Finów, którzy znacząco przyczynili się do rozbudowy floty.

W kwestiach działań wojskowych nadal do opracowania pozostaje udział oddziałów szwedzkich i fińskich wiernych królowi w działaniach w Inflantach, zwłaszcza na początku wojny w latach 1600-1605. Równie skomplikowane są zagadnienia dotyczące tworzenia przez uchodźców baz szpiegowskich w Danii, a także działań podejmowanych przez nich w Szwecji. Można stwierdzić, że problematyka została już naszkicowana, lecz wymaga zebrania i uporządkowania. Można to zrobić tylko po gruntownej kwerendzie w archiwach duńskich oraz szwedzkich ${ }^{10}$.

Sprawy szwedzkie były po 1600 roku przedmiotem debaty politycznej w Rzeczpospolitej. Wydaje się jednak, że sama kwestia uchodźców nie stanowiła większego problemu, była traktowana przez szlachtę instrumentalnie jako wygodny argument w debatach o nadmiernych wpływach cudzoziemców. Tak było choćby w czasie rokoszu sandomierskiego, ale ostatecznie strona królewska wyszła z tego starcia zwycięsko. W konstytucjach z 1607 i 1609 roku zawarte zostały przepisy umożliwiające niewielkiej grupie szwedzkich urzędników pozostawanie u boku króla, będącego przecież formalnie władcą Szwecji oraz Finlandii ${ }^{11}$.

${ }^{8}$ W. Łygaś, Gdańsk. Szwedzkie karty historii, Gdańsk 2001; S. Kościelak, Gdańsk XVI-XVIII wieku - bezpieczna przystań dla religijnych uchodźców? Z dziejów koegzystencji międzywyznaniowej w epoce nowożytnej, „Studia Historica Gedanensia” 2014, t. 5, s. 196-216.

${ }^{9}$ M. Huflejt, Bitwa pod Oliwa 1627. Fakty i mity, Olsztyn 2019, s. 60-65.

${ }^{10}$ W. Krawczuk, Wierni królowi, s. 79-85.

${ }^{11}$ A. Pawłowska-Kubik, Rokosz sandomierski 1606-1609. Rzeczpospolita na politycznym rozdrożu, Toruń 2019, s. 150, 152, 194. 
Należy stwierdzić, że mimo badań pokoleń historyków z różnych krajów temat uchodźców ze Skandynawii w czasach Zygmunta III daleki jest od zamknięcia. Obfitych wyników spodziewać się można po kwerendach archiwalnych w Sztokholmie i w Kopenhadze. Losy uchodźców mogą pomóc w zrozumieniu nie tylko ich samych, lecz także przyjmujących ich społeczności.

\section{BIBLIOGRAFIA}

\section{Źródła rękopiśmienne}

Riksarkivet Stockholm, Riksregistraturet, vol. 87

\section{Opracowania}

Huflejt M., Bitwa pod Oliwa 1627. Fakty i mity, Olsztyn 2019.

K ośc i elak S., Gdańsk XVI-XVIII wieku-bezpieczna przystań dla religijnych uchodźców? $Z$ dziejów koegzystencji międzywyznaniowej w epoce nowożytnej, „Studia Historica Gedanensia" 2014, t. 5, s. 196-216.

Krawczuk W., Wierni królowi. Szwedzi i Finowie w Rzeczpospolitej Obojga Narodów w pierwszej połowie XVII wieku, Kraków 2019.

Leitsch W., Das Leben am Hof König Sigismunds III. von Polen, Bd. I-IV, Wien 2009.

Łyg ás W., Gdańsk. Szwedzkie karty historii, Gdańsk 2001.

Małłek J., Stosunki kulturalne Polski i Litwy z państwami skandynawskimi w późnym średniowieczu i w czasach nowożytnych (1385/1397-1795) [w:] Kultura Pierwszej Rzeczypospolitej w dialogu z Europą. Hermeneutyka wartości, t. 1: Wśród krajów pólnocy. Kultura Pierwszej Rzeczypospolitej wobec narodów germańskich, słowiańskich i naddunajskich: mapa spotkań, przestrzenie dialogu, red. M. Hanusiewicz-Lavallee, Warszawa 2015, s. 58-102.

Michalewicz J., Dwór szwedzki Zygmunta III w latach 1587-1600, „Odrodzenie i Reformacja w Polsce" 1966, t. XI , s. 161-180.

Nag iels ki M., Społeczny i narodowy skład gwardii królewskiej za dwóch ostatnich Wazów (1632-1668), „Studia i Materiały do Historii Wojskowości” 1988, nr 30, s. 61-102.

P awłows ka-Kubik A., Rokosz sandomierski 1606-1609. Rzeczpospolita na politycznym rozdrożu, Toruń 2019.

Szpaczyński P.P., Mocarstwowe dążenia Zygmunta III w latach 1587-1618, Kraków 2013.

Ślaski K., Bninska P., The Swedish Emigrants in Poland on the Turn of the $16^{\text {th }}$ Century and Their Part in the Social Life of this Country, „Studia Historica Slavo-Germanica” 1983, vol. 12, s. 155-163. 
